\title{
NOTES ON PS 101 (LXX) AND PS 103 (LXX) IN HEBREWS 1 IN THE LIGHT OF EVIDENCE FROM THE DEAD SEA SCROLLS AND PAPYRUS BODMER XXIV
}

\author{
Gert J. Steyn \\ University of Pretoria
}

\begin{abstract}
Ps 102(101) is only quoted explicitly in Heb 1:10-12 in the whole of the corpus of known early Jewish and early Christian literature. It is a complex Psalm, containing an individual's lament who grieves for Zion, but ends in a song of praise about the unchangeableness of God. It is especially the LXX that opens up the possibility for a Christological interpretation in Hebrews - principally with its inclusion of kurio of which the Hebrew equivalent lacks in the Hebrew texts. There are furthermore elements in Ps 102(101):13-21 that were probably taken as references to Christ: his enthronement, the liberation from fear and death, the reference to this "to be written down for a future generation," and the renewal of Zion. Ps 104(103) was probably used during the Jewish synagogue liturgies on Friday evenings and Sabbath mornings. In the early Christian period, Ps 104(103) was traditionally used on Ascension Day from the earliest days of the Christian Church. It is quoted in Heb 1:7, but is nowhere else quoted or alluded to in the NT. The idea derived from the quotation of Ps 104(103):4, regarding the submission of the spirits (angels) to Christ, is picked up again in the conclusion to the catena of Heb 1 . They are merely liturgical spirits in the service of God (Heb 1:14).
\end{abstract}

\section{Introduction}

Psalm 102 (LXX 101) and Psalm 104 (LXX 103) belong to Book IV of the Psalms, i.e. Pss $90-106 .{ }^{1}$ Quotations from these two Psalms are only to be found in Hebrews 1 in the whole corpus of known early Christian literature. It is especially the LXX versions of these Psalms that open up the possibility for a Christological interpretation in Hebrews. The origin and purpose of these quotations in Hebrews 1 contributes to our 
understanding of why the unknown author of Hebrews chose these Psalms and how he applied them within their new embedded context.

\section{Psalm 102(101):26-28 in Heb 1:10-12}

The Son's superiority over the angels is emphasized by the quotation from Ps 102(101):26-28 in Heb 1:10-12. He was present and active as an agent at the creation and his nature is stable, immutable and permanent, whilst the angels are transitory and the whole of creation temporary. ${ }^{2}$ Even the simile ${ }^{3}$ of creation as a garment ("that changes, gradually deteriorates, is eventually rolled up and discarded," (Kistemaker 1984:46), v. 27) is included in the quotation, with its accompanying contrast with God's eternity (v. 28). Schunack is thus correct in saying that this "metaphorische" (sic!) expression does not carry independent weight and does not contain a reference to the end of the world (2002:28). The perception that heaven was seen like a tent that was stretched over the world (Ps 104:2; Isa 40:22) made it easier to think of it as being rolled up (Koester 2001:196). Striking is also the analogy with Isa 50:9 (p a nt e umei : wf imation pal aiwghsesqe) and Sir 14:17 (pas̀ sarx wf imatrion palaioutai), which compare aging human beings with a garment.

\subsection{Background Regarding Ps 102(101)}

Ps 102(101) is a complex Psalm, containing an individual's lament (Westermann 1980:55; Rüsen-Weinhold 2001:182; Guthrie 2007:940) who grieves for Zion, but ends in a song of praise about the unchangeableness of God (Kistemaker 1984:45). Verses 13-23 and 26-29 are possible additions that were made for the purpose of giving the psalm a collective sense (Allen 1983:11). It belongs to the group of Psalms known in the ancient Church as "Penitential Psalms," or "Bußpsalmen,"4 and was probably used in public worship, perhaps with particular use during the evening liturgy. ${ }^{5}$ Verses $2-12$ and 24-25 contain an individual's lamentation; vv. 13 and 26-28 contain hymnic elements; and vv. 14-23 and 29 contain elements of prophetic promises (Kraus 1978b:864). The first person prayer, which is introduced with anh in v. 25, was probably a fixed liturgical formula that was incorporated by the psalmist into his composition (Henze 2005:179). Structurally, most scholars envisage the Psalm as follows:
A. vv. $2-12=$ Individual's lamentation
B. v. $13=$ Hymnic section

\section{POSSIBLE ADDITION \\ C. vv. 14-23 = Prophetic section \\ A. vv. 24-25 = Individual's lamentation \\ B. vv. 26-28 = Hymnic section}

\section{POSSIBLE ADDITION}

C. v. $29=$ Prophetic section 
The Psalm presents a clear correlation between the eternal existence of God and the "Wohnen" and "Bestehen" of his people (Gzella 2002:146). The focus of vv. 26-28 - the section from which the author of Hebrews quotes - is that God's rule is eternal and that he is the Creator and Judge of the world. Weiser finds these aspects belonging "to the constitutive basic ideas of the festival cult" (1982:655). The supplicant sees his suffering against the backdrop of God's imperishability and creation abilities (Burden 1991:22-23). Even earth and heaven, the creation of God's hands, might pass away, but God will remain forever. The hymn leads to a promise in v. 29, which in anticipation, arises from trust and hope as "he makes confident supplication for mercy and restoration for himself and Zion" (Bruce 1985:21). It is noteworthy that the person who prays focuses not on the past, but finds consolation in God's future acts (Kraus 1978b:869).

\subsection{Ps 102(101) in the Early Jewish and Christian Traditions}

Ps 102(101):27 and Isa 51:6 show close resemblances with each other - especially with hJ de; gh 'wf imation pal ai wqh set a i occurring in both - and a possible allusion to the same verse (v. 27) is also to be found in Jacob's Ladder 7:35. ${ }^{6}$ There are, however, some significant problems in considering this allusion due to the untrustworthiness of the text in its specific form (Guthrie 2007:940). None of the other verses of this Psalm are explicitly quoted anywhere else by anyone in the early Jewish or early Christian literature known to us today. ${ }^{7}$ Ps 102 thus has no other explicit citations that can be found in the entire NT. One could therefore cautiously assume that the author of Hebrews found this quotation by himself, somehow deciding upon using this particular Psalm and these particular verses. It is used later in the early Christian tradition by Irenaeus (Haer. IV, 3.1).

\subsection{Readings of Ps 102(101):26-28}

Starting with the Hebrew witnesses, the text of the quotation that is used by the author of Hebrews is covered by two fragments amongst the finds of the DSS, namely 4QPs ${ }^{b}$ col. XXII,1-6 (4Q84) which contains the section Ps 102:10-29, and 11QPsa (11Q5) which covers Ps 102:18-29 (Washburn 2002:97). The first of these, 4QPs ${ }^{\mathrm{b}}$, is in complete agreement with the MT (De Waard 1965:27), but not the latter (11QPsa).

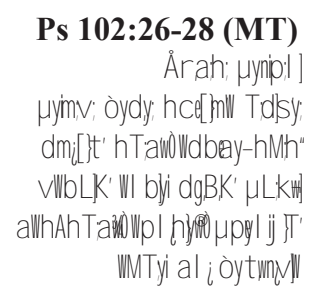

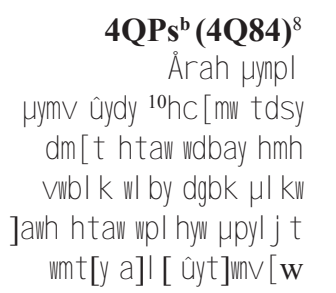

$11 Q P s^{\mathrm{a}}(11 \mathrm{Q} 5)^{9}$

]v hkdy we[ nahdsum

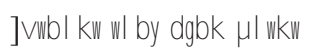

untoyaw hkyt waw

Turning to the Greek witnesses, there are a number of minor variant readings amongst the LXX texts, which do not carry enough text critical weight to be considered as replacements for the existing reconstructed text of Rahlfs. The reconstructed reading 
of the LXX, though, is close to that as represented by PBod XXIV (cf. Kasser \& Testuz 1967:200-201). It is worth noting that none of the possibilities, as suggested by the variant readings of the LXX, is attested to by PBod XXIV.

\author{
PBod XXIV ${ }^{11}$ \\ kat arca k kĩnt hn ghn su \\ eqemel iwsa : kai erga twn ceirwn \\ eising oi ouranoi : autoi apolouñai su \\ de di amenei $\sim$ : kai pante $\sim$ w i imation \\ pal ai wahs ont a i : ws ei peribol eo \\ al laxei aut ou kai al laghsont ai : \\ su de o auto jei kai ta eth sou ouk \\ ekliyous in
}

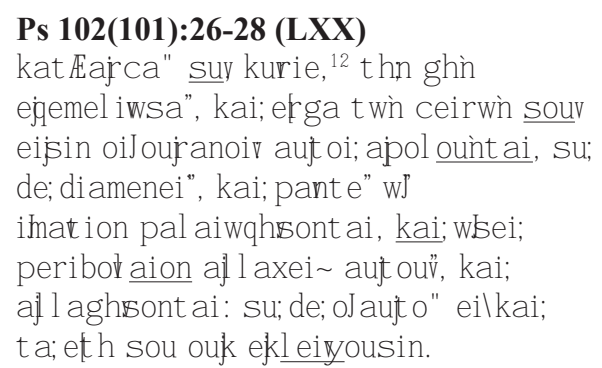

When one compares the Hebrew and Greek witnesses with each other, the MT and LXX versions of Ps 102(101) differ significantly (Guthrie 2007:940). The following differences should be noted in the passage that is quoted: Some Hebrew manuscripts, $11 \mathrm{QPs}^{\mathrm{a}}$, the LXX and the Targum agree with each other in reading the plural ("works":

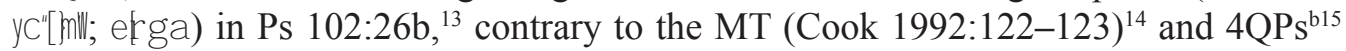
which read the singular (òdy hceis, Further differences are that the LXX translators inserted kurie in Ps 101:26a (LXX) - with possible influence from vv. 2 and 13 (Ahlborn 1966:115) - although its equivalent lacks in the MT. The words su;... ap jajch $\sim$, kurie are also to be found in Wis 9:7-9 and, apart from the fact that this passage has many parallels with Hebrews ${ }^{16}$ one might assume that it was a fairly common confessional phrase - which should call for caution in trying to find a written Vorlage for it. Another difference is that the LXX reads in Ps 101:27b palaiwghsont ai ("will wax old"as in Heb 1:11b) whereas the MT has Wbyy ("wear out/away") (Archer \& Chirichigno 1983:81). The LXX reads in Ps 101:28 ekl ei y ous in ("shall come to an end" - as in Heb 1:12c), which confirms the readings of Ps 102:28 (MT) and 4QPs $s^{\mathrm{b}}$ : WTy This is one of three existing orthographical variants that have parallels in the OT. ${ }^{17}$ An interesting case is the presence of the copulative ka i vbefore w\$ ei, which is attested by all the LXX witnesses (except PBod XXIV) and by the Hebrew text of 11QPs ${ }^{\mathrm{a}}$. It is however omitted by the Greek witness PBod XXIV (2110), the Hebrew of the MT and 4QPs ${ }^{\mathrm{b}}{ }^{18}$

\subsection{Alternative Readings of Heb 1:10-12}

The majority of witnesses ${ }^{19}$ omit w' i matvion in Heb 1:12, but its inclusion is attested by the oldest and most important witnesses ( $\mathrm{P}^{46}$ a A B) (Elliott 2000:211). POxy LXVI (4498) also includes $\mathrm{W} \sim \mathrm{i}$ ma ] $\mathrm{i}$ [ $\mathrm{On}$ as part of the text. Its omission could be accounted for due to assimilation to the LXX (Metzger 1975:663; Wilson 1987:43). There is thus little doubt that the phrase should be included. Furthermore, the reading ef i x ei" in Heb $1: 12$ is attested by $\mathrm{J}^{46} \mathrm{~A} \mathrm{~B}$ - and should be taken as the most authoritative based on this combination of witnesses. The variant a I a xei , which is the same reading as that of the LXX, is followed by $a^{*} \mathrm{D}^{*} \mathrm{t} \mathrm{vg}^{\mathrm{cl.ww}}$; Ath. ${ }^{20}$ 


\subsection{A Comparison of the Readings of Ps 102(101):26-28 with Heb 1:10-12}

Based on the discussions above, the existing readings of the eclectic texts could thus be used for the purposes of comparison.

\begin{tabular}{|c|c|}
\hline $\begin{array}{l}\text { Ps 102(101):26-28 LXX } \\
\text { kat Fajca" supkurie, thnghǹ }\end{array}$ & $\begin{array}{l}\text { Heb 1:10-12 } \\
\text { su;kat Eajcav, kurie, thnghǹ }\end{array}$ \\
\hline égemel i wsa , kai;elga t wǹ c eirwǹ souv & égemel iwsa", kai; elga t wh̀ c eir wh̀ souv \\
\hline eiśin oijousanoiy & eiśin oijousanoiy \\
\hline 27 a uf oi;apol ount ai, su;de;dia menei , & 11 a uf oi;a pol ount ai, su;de;dia menei r, \\
\hline kai;pante wf imation & kai;pante w imation \\
\hline pal aiwghsont ai, & palaiwqhont ai, \\
\hline kai;wsei;peribovaion a|laxei & 12 kai;wsei;peribovaion el ixei \\
\hline a uf out, & a uf. ouv, \\
\hline kai;a llaghsontai: 28 su;d & w imation kai;all aghsont ai: su;de;0l \\
\hline eilkai;ta;efh sou ouk ekl & $\begin{array}{l}\text { a uf o eilkai;t a; eth sou ouk } \\
\text { ekl eiy ous in. }\end{array}$ \\
\hline
\end{tabular}

The major differences between the reconstructed readings of the LXX and the NT texts seem to be the following:

- Whereas Ps 101:26 (LXX) reads kat Eajcair suv- calling to mind the creation account in Genesis (Kistemaker 1984:46), Heb 1:10 reads su; kat Eaj ca . The second person personal pronoun, $s$ uy thus seems to be transposed to the beginning of the quoted text in the NT, and now occupies the most prominent emphatic position (Kistemaker 1961:26; Ahlborn 1966:115; Weiss 1991:167; Grässer 1990:88; Rüsen-Weinhold 2001:184). This transforms the quotation into a more parallelistic (hymnic?) structure with three $s$ u-sentences: $s u ; k a t$ jaj ca $a$... egemel iws a (v. 10a); s u;de;dia merrei (v. 11a); and s u;de; 0 a uf or (v. 12c). ${ }^{21}$

- Whereas the LXX text probably read the future diamenei $\sim$ based on the future form of the MT and followed by some NT witnesses ( $\mathrm{D}^{2}$ 0242. 365. 629 pc lat), the main authoritative NT text tradition suggests dia menei (Schröger 1968:66; Grässer 1990:88). The circumflex of the LXX was thus replaced with an acute accent on the third syllable in the NT case. The difference would not have been noticable in the uncials due to absence of accentuation there, but it would have been detected from the context.

- Whereas the LXX text probably read a I l axei , the author of Hebrews seems to have changed it to ef i xei (Ellingworth 2000:129 passim). ${ }^{22}$ The verb a I I \& S W is consistently used in the LXX (a) I axei , a I laghsont ai). It might also go back to a common early Christian tradition as it is used in 1 Cor 15:51 similar to the "putting on" of immortality (Ellingworth 2000:129). The verb ef is s w is used in Isa 34:4 LXX for heaven which will be rolled up like a scroll ( $\mathrm{kai}$; el ighs et a i of oujano; wf biblion $)^{23}$ and also in the apocalyptic text of Rev 6:14 when heaven 
will disappear like a scroll which is rolled up (0Jour a no; a pec wris gh wh bibl ion ej is somenon).

- It can be assumed that the NT read wl' imation in Heb 1:12, whereas the phrase does not occur at all in any of the extant LXX witnesses. The inclusion of the phrase replaces the comparison in the Psalm with that of a rolled up cloak (Brunert 1996:20; Attridge 1989:61) and is deliberately added by the author ${ }^{24}$ to show that the simile of the garment is continued (Metzger 1975:663). Some scholars, though, assume that the author of Hebrews found this phrase in his Vorlage. ${ }^{25}$

Summa: Despite the categorical statement of some scholars (Bacon 1902:280; Klijn 1975:34) that the quotation from Ps 102(101):26-28 agrees with the LXX, it is clear that this quoted text in Heb 1:10-12 does not agree completely with Ps 101:26-28 LXX. ${ }^{26}$ It is, nonetheless, clear that the reading of Hebrews is closer to the LXX versions than to the Hebrew and it follows the same deviations from the MT as most LXX witnesses. The presence of kuri $0 \sim$ and of the included kai vbefore ws ei (in the LXX but not in the MT or DSS), is already enough evidence for this.

\subsection{Some Remarks on the Interpretation of the Quotation Context of Heb 1:10-12}

The connection between this quotation and the former remains very close despite the fact that it introduces a new idea (Westcott 1974:28). This is achieved with a single ka ivthat is used as introductory formula. It forms part of the author's evidence with the quotation from Ps 45(44) what God said about the Son (pro; de; t on uipr, 1:8) and stands in direct contrast with what God said about the angels (pro $\sim$ men tou $\sim$ ag gevou , 1:7) (Grässer 1990:87).

This Psalm, which is addressed to God the Creator, is now taken out of its context and used in connection with the status of the Son (Bacon 1902:280; Combrink 1971:28; Bruce 1985:21; Wilson 1987:42; Koester 2001:195). ${ }^{27}$ The Christian interpretation of Ps 102(101) starts here in Heb 1:10-12 when words that were initially addressed to Yahweh (not to the messiah), are now applied by the author "in leichter Abwandlung" to Christ (Brunert 1996:20; Cody 1960:108). It is precisely due to the inclusion of the term kuri o in the LXX, that the activities in Ps 102(101) could be transferred to Christ (Kistemaker 1984:46). It is especially the LXX that opens up the possibility for a Christological interpretation (Combrink 1971:28) - principally with its inclusion of kuri $0 \sim$ of which the Hebrew equivalent lacks in the Hebrew texts. There are furthermore elements in Ps 102(101):13-21 that were probably taken as references to Christ: his enthronement, the liberation from fear and death, the reference to this "to be written down for a future generation," and the renewal of Zion (Ellingworth 2000:125). The Zion motif of Ps 102(101):14-17 is interesting in the light of Heb 12:22ff. In the Psalm there is a cry of hope for the reparation of Zion in the midst of suffering (perhaps from post-exilic times) (Van Oyen 1962:19). One should thus consider a version of the LXX as point of departure for establishing the Vorlage of this quotation. 
Ps 102(101) serves as proof for the author of Hebrews about the control of the Son of God over the world, and in a broader sense the fulfilment of the divine promises in Christ (Brunert 1966:20). ${ }^{28}$ Creation that owes its existence to the Son (Heb 1:2) is temporary and will pass away. Christ, on the other hand, who inherits all (1:2) and is God's Son (1:5), is permanent and eternal. In this manner, the quotation covers in two parts the Son's activity in both the beginning (v. 10) and the end of time (vv. 11-12) (Ellingworth 2000:126).

\subsection{Conclusion to the Quotation of Ps $101 \mathrm{LXX}$}

No evidence is found that this Psalm has been explicitly quoted anywhere else in the early Jewish or early Christian literature prior to the time of Hebrews. The author of Hebrews might thus have identified this quotation himself as an appropriate text for his argument. The text critical study of Ps 102(101):26-28 made it clear that this quoted text in Heb 1:10-12 does not agree completely with the LXX version, although being closest to it by showing the same deviations from the MT as the LXX does.

\section{Ps 104(103):4 in Heb 1:7}

The author of Hebrews continues his contrast between the p r wt ot ok o of the previous verse (Heb 1:6) and the a g gel oi with this next verse (Heb 1:7). Both these quotations emphasize the inferior position of the angels, because the Son and the angels are different beings or entities. ${ }^{29}$ The angels are spirits, created by God to be servants. ${ }^{30}$ They were told to worship the Firstborn when he was brought into the world (Ode 32:43) and their offices are ministerial and transitory, being made winds and flames of fire (Ps 104[103]:4). They carry the "flaming fire" (p ur f I egon) of God's glory that he has shown on Mount Sinai (Exod 24:17) (Ellingworth 2000:121; Karrer 2002:136).

\subsection{Background regarding Ps 104(103)}

Just as would later be the case with Pss 45(44) and 95(94) which are quoted by Hebrews, also Ps 104(103) belongs to the grouping of hymns or Psalms of praise. ${ }^{31}$ It is a preexilic Psalm, "somewhere between the mythical creation picture of Psalm 74 and the sober fiats of Genesis 1" (Goulder 1998:294). It also belongs, with Ps 8 (quoted later in Heb 2), to those Psalms that are allusions to God's creation and is called a "creation Psalm" (Westermann 1980:97; Westcott 1974:24; Kistemaker 1984:41; Vos 2005:236) - with its perspective on the continuing role of God's breath of life (òj $0 ;$ t p neumav s ou, v. 30) in the process of creation (Spieckermann 1998:150). (Compare this with the t/j W ykal thor t ou $\sim$ a g g evou a uf ou 'p neumat a of v. 4 that is quoted in Heb 1:7).

Two aspects regarding Ps 104(103) that were proposed in the past are controversial. The first is its possible connections with the key document of Atonism, the great Egyptian Sun Hymn from Tell el-Amarna, also known as the Hymn of the Aten. Due to many similarities, some scholars (Kraus 1978a:884; Breasted 1946:371; West 1981:442; Baly 
1974:69; Rogerson \& Davies 1989:94; Vos 2005:249) found dependence of Ps 104(103) upon this hymn to the sun god Atum, Aten or Re by the Pharaoh Akhenaton. ${ }^{32}$ Others are sceptical about this view - especially to connect Hebrew monotheism to Egyptian origin, arguing that "many of the thoughts present in the Sun Hymn can be found in Egyptian religious literature from both before and after the Amarna period, and are not the creation of Akhenaton and his scribes and priests" (Aling 1981:130). Nevertheless, the connection with the Sun Hymn is fairly widely accepted.

The second controversial aspect regarding Ps 104(103) is a possible connection with some kind of festival - whether this be a New Year's festival (Humbert 1935:127; Allen 1983:28-29), an autumn festival or merely a creation festival (Mowinckel 2004:140-146; Goulder 1998:107; Weiser 1982:666 passim). This viewpoint has lost momentum, has been criticized (Kraus 1962:239) and is not widely accepted at all.

\subsection{The Use of Psalm 104(103) in Early Jewish and Christian Traditions}

Ps 104(103) was probably used during the Jewish synagogue liturgies on Friday evenings and Sabbath mornings (Kistemaker 1961:23; 1984:41; Werner 1959:150). Verse 4, which is quoted in Heb 1:7, has also been alluded to by early Judaism in the Dead Sea Scrolls. There are three places where possible allusions to this text were identified amongst the Dead Sea Scrolls. The first is within the section 1QS 1:16-2:25, which describes the ceremony of the Feast of the renewal of the Covenant (Vermes 1977:178). The listed passage (1QS 1:21-22) is questionable, however, as it only talks about the priests and the Levites who will recite the just deeds of God in his mighty works. The second is within 4QWorks of God (4Q392). ${ }^{33}$ The third case, from the Hodayot (1QH 1:10b-12) can indeed be identified as an allusion. ${ }^{34}$ It was thus in principle not an unknown phrase. Furthermore, the broader motif of the angels being flames of fire, and also spirits and winds, was a known motif amongst the community at Qumran. ${ }^{35}$

In the Greek Jewish literature, although Ps 104(103):4 is not explicitly quoted in the extant literature, the term p neumat a appears in the $\mathrm{LXX}^{36}$ and the motif of the I eit ourgoi; qeou ' is a known motif in Philo ${ }^{37}$ and in the LXX ${ }^{38}$ Further allusions to Ps 104(103): 4 are also to be found in the pseudepigraphal literature. ${ }^{39}$

In the early Christian period, Ps 104(103) was traditionally used on Ascension Day from the earliest days of the Christian Church (Vos 2005:249-250). This quotation is found in 1 Clem 36:3, as well as Ps 2:7 following in 1 Clem 36:4 - probably due to the influence of Hebrews. Although Ps 104(103):4 is nowhere else quoted or alluded to in the NT itself in any other place, the term I eit our goi ; qeou 'appears only once more in the NT (Rom 13:6). Broader knowledge of Ps 104(103) is also clear from the fact that v. 12 was quoted in the Synoptic gospels during the parable of the mustard seed (Mark 4:32, par. Matt 13:32; Luke 13:19). An allusion to Ps 104(103):25 is also to be found in Rev 19:1 when the great multitude praises God in heaven - which confirms the possible liturgical use of this Psalm in early Christian times. 


\subsection{Readings of Ps 104(103):4}

Comparing the Hebrew witnesses, Ps 104:4 is the most widely covered amongst the findings of the Dead Sea Scrolls from all the Psalm quotations that occur in Hebrews. Three different fragments contain the verse used in the quotation of Heb 1:7: 4QPs ${ }^{\mathrm{d}}$ (4Q86) has the section of Ps 104:1-5 preserved; 11QPsa (11Q5) contains the section of Ps 104:1-6, and 4QPs ${ }^{1}$ (4Q93) contains Ps 104:3-5. When these readings are compared with that of the MT, the situation appears as follows:

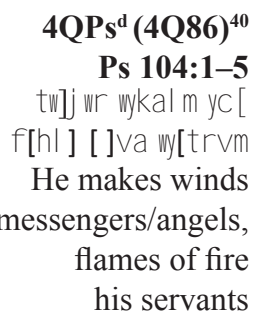

11QPsa $(11 Q 5)^{41}$
Ps 104:1-6
]a[ ]
tfhw va ut [
[who make the
winds his
mess]en[gers,]
flaming fire
his [ministe]rs

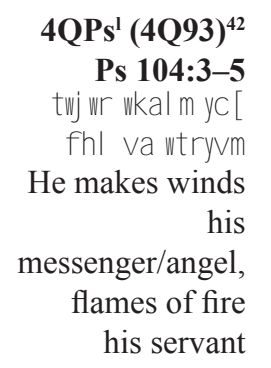

MT

Ps 104:4

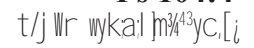

fheivaestrym

He makes winds

messengers/angels,

flames of fire

his servants

The readings of the three Dead Sea Scrolls fragments and that of the MT are very close. $4 \mathrm{QPs}^{\mathrm{d}}$ and the MT are identical, whereas 11QPs a reads "flaming fire" (similar to the LXX p ur f I egon), not "flames of fire," and 4QPs' reads "messenger" and "servant" in the singular, not the plural.

Amongst the Greek witnesses to Ps 104(103):4, particularly noteworthy is the $2^{\text {nd }} /$ $4^{\text {th }}$ cent. C.E. ${ }^{44}$ PBod XXIV (Ra 2110) (cf. Fraenkel 2004:58-61).

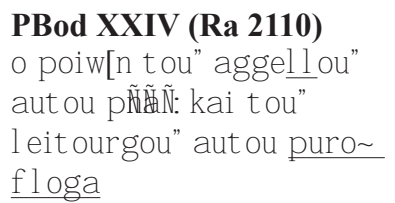

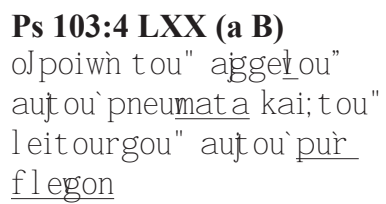

The reading of PBod XXIV seems to be closer to the NT text (Kasser \& Testuz 1967:204). It reads $p$ N̂̃̂̃ N (probably for p neuma rather than for p neuma t a ) (Pietersma 1978:46), ${ }^{45}$ as well as puro $\sim \mathrm{fl} \log \mathrm{a}-$ as it is found in the quotation of Heb 1:7.

There are two clear traditions (probably due to the rabbinic traditions regarding the mutability of angels) (Ellingworth 2000:121) ${ }^{46}$ that can be identified here and which are due to the interchange or switching of the subjects: ${ }^{47}$

- God makes "the winds his messengers ${ }^{48}$ and flames his servants." This version is followed by the MT. ${ }^{49}$ Also 1QH 1:10-12 takes the same approach by praising the unlimited possibilities of the Creator who could even use the natural elements as his messengers (Grässer 1990:81).

- God makes "the angels winds and his servants flames of fire." This is followed by the LXX, ${ }^{50}$ Targum Jonathan (Schröger 1968:58) and Hebrews. The Syrian and other eastern versions of 2 Esdras (4 Ezra) 8:21f. follow a similar direction by referring to the angels who "are changed to wind and fire" (Bruce 1985:18). Also 
the interpretation in the Latin version of this passage refers to the angels "whose service takes the form of wind and fire" (Bruce 1985:18). ${ }^{51}$

\subsection{Alternative Readings of Heb 1:7}

The only variant reading regarding the text of the quotation in Heb 1:7 as documented in NA27, is that of the Western text $\mathrm{D}$ (followed by 326. $2464 p c \mathrm{sy}^{\mathrm{p}}$ ), which reads p neuma and not $p$ neumat $a$ as the rest of the witnesses. The difference might be explained by being due to either the assimilation with $f$ I oga, or because the abbreviation $p$ Ñ̃̃ Ñwas used for both p neuma and for pneumat a (Ellingworth 2000:121). Thus, there is little doubt that p neumat a should be the preferred reading - in the light of the combined support of $\mathrm{P}^{46}$ and Codex $\mathrm{B}$, as well as the support of codices $\mathrm{a}$ and $\mathrm{A}-$ so that the choice of NA27 should be accepted.

POxy LXVI $(4498)^{52}$ - also known as $\mathrm{P}^{114}$ - is one of the latest additions to the pool of variants to Heb 1:7-12. The fragment is an uncial manuscript and is dated to the $3^{\text {rd }}$ cent. C.E. It was first published in $1999^{53}$ and has not yet been incorporated into the critical text of NA27. The piece is identified to be the text of Heb 1:7-12 as it clearly contains parts of the three texts quoted there and in the same sequence too, namely Ps 104(103):4; Ps 45:7-8(44:6-7) and Ps 102(101):26-28. Unfortunately, not much can be deduced from this fragment. Both the reading of LXX PBod XXIV and Heb 1:7 ( $p$ ur $0 ;$ $\mathrm{f}$ I oga, total 39 characters) as well as that of the LXX a B (pur $f$ I egon, totalling 38 characters) is theoretically possible.

\subsection{Comparison between the Readings of Ps 104(103):4 and Heb 1:7}

Scholars are in agreement that the quotation from Ps 104(103):4 in Heb 1:7 agrees verbally with the LXX (Kistemaker 1961:23; 1984:41; Schröger 1968:56; Westcott 1974:24; Klijn 1975:33; Bruce 1985:17; Wilson 1987:41; Karrer 2002:136) - against the reading of the MT. This is only partially true, ${ }^{54}$ as there is still the unaccounted difference between pur flegon (LXX Ps 103:4) and pur o" floga (Heb 1:7). The latter, a well-known phrase in the NT, which is also supported by the LXX witnesses Bo Sa $L^{\mathrm{b}} \mathrm{A}^{\mathrm{c}}(\mathrm{f} \text { I ega ! })^{55}$ in Ps 104(103):4, is most probably due to a "back reading" (Katz 1955:135), ${ }^{56}$ or later adaptation in these LXX witnesses on the basis of the NT text (Walters 1973:323; Ellingworth 2000:121).

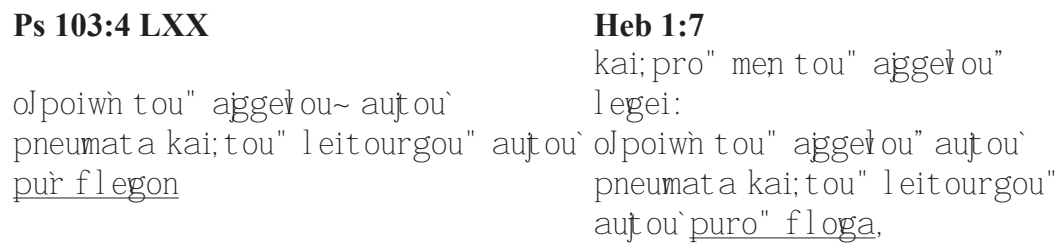

Some saw this difference between the pur f I egon of the LXX and the pur o" fIoga 
of Hebrews as a mere stylistic improvement. If this was the case - which is possible with regard to the Lucianic witnesses - then this reading could have entered the LXX witnesses already independently from the NT as such an improvement. Furthermore, the Boharic and Sahidic LXX translations are not known to show NT influence (Ahlborn 1966:112). It became clear from the discussion above that, given the evidence of PBod XXIV, there is a definite possibility that the Vorlage of Hebrews actually reads p ur 0 " f I oga (Rüsen-Weinhold 2001:179) - which is confirmed by the Coptic translations. ${ }^{57}$ It seems best to accept Ahlborn's conclusion:

Die Variante puro" f Ioga ist relativ alt und im oberägyptischen Raum nachgewiesen. Dort könnte auch die Vorlage des Hebräerbriefes beheimatet sein; wenigstens ist sie von daher beeinflußt. Später hat sich die Lesart dann in einem Teil der Zeugen für die lukianische Rezension gehalten (Ahlborn 1966:112).

Unless one could prove that the author made definite changes due to his applied context, the chances are thus great that the quotation in Heb 1:7 would be based on a Vorlage similar to that represented in PBod XXIV and that it actually read the same as the text of the quotation in Hebrews - reading $p$ ur $0 ; f$ I 0 ga.${ }^{58}$ Furthermore, the similarity between wf imatrion in LXX Ps 103:2, 6 and Heb 1:12 certainly is interesting and might even be an indication that the author of Hebrews read, or knew, the broader context of Ps 104(103) (Ellingworth 2000:121).

\subsection{Some Remarks on the Interpretation of the Quotation Context of Heb 1:7}

The text of this LXX quotation from Ps 104(103):4 is presented in the form of a synthetical parellismus membrorum (Weiss 1991:164). Whereas the MT and 1QH I,1011 state that God could make elements of nature, such as wind and fire, his angels, the LXX and Hebrews have another theological understanding. According to the latter, God can reduce the angels to be natural elements (Koester 2001:194).

The term "spirits" is used around the turn of the first century not less than twenty times in the Songs of the Sabbath Sacrifice (ShirShabb) alone (Karrer 2002:136). In 1 Cor 14:32, "the spirits of prophets (p neumata prof ht wn) are subject to (up ot a s s et a i) the prophets," with the intention that these spirits through whom those prophets speak, submit themselves to the control of the prophets. The spirits that were the objects of exorcism in the NT were also known as p neumat $a^{59}$ - the same kind who let the people who were possessed with them fall down before (prosepipt on) Jesus and acknowledged him as the Son of God (s u; eilof uib; t ou 'qeou', Mark 3:11), who submitted themselves (up ot a s s et a i) to the 72 disciples (Luke 10:20), and who were helpless when confronted with the name of the Lord Jesus (Acts 19:12-13). In the cases mentioned here, there is a special "heavenly" connection with the names of Jesus and the disciples - an aspect which strongly reminds one of Heb 1:4 from which the catena of quotations provides the evidence that Christ is superior to the angels. The 
idea derived from the quotation of Ps 104(103):4 regarding the submission of the spirits (angels) to Christ,${ }^{60}$ is picked up again in the conclusion to the catena of Heb 1 . They are merely "liturgical spirits in the service" of God $^{61}$ (l eit our gika; pneumat a eif diakoni an, Heb 1:14). ${ }^{62}$

\subsection{Conclusion to the Quotation from Ps 103 LXX}

It became clear that the use of this Psalm is closely linked with a clear liturgical tradition and that allusions to it occur frequently in early Jewish and early Christian literature. Motifs such as the angels being flames of fire, spirits and winds, was an accepted motif within the community at Qumran and the motif of the l eit our $\mathrm{g} 0 \mathrm{i} ; \mathrm{qe}$ ou ' is a known motif in Philo and in the LXX. Furthermore, the term p neumat a appears a number of times in the LXX. Although the Psalm and related motifs from it were thus well known by the time the author of Hebrews wrote, the fact that there are no traces of this specific explicit quotation being used before his time should probably point in the direction of Hebrews' own identification and utilisation of these lines. This might be due to knowledge from its liturgical use in the tradition or to the author's own study of his Scriptures.

The text critical investigation of Ps 104(103) made it clear that there were two traditions: (a) The MT and 1QH 1:10-12 support "the winds his messengers and flames his servants," whilst (b) the LXX, Targum Jonathan and Hebrews - as well as the Syrian and other eastern versions of 2 Esdras - support God making "the angels winds and his servants flames of fire." The investigation, furthermore, discovered that there is a definite possibility that the Vorlage of Hebrews actually read pur o" f I og a - based on the evidence of PBod XXIV. The quotation assists in the author's argument that the Son is superior to the other sons of God. The scene is that of the Son enthroned in heaven with the angels in a serving capacity.

\section{NOTES}

1 See Hossfeld (2001:163-169) for a discussion on the differences between the MT and LXX within this collection.

2 Cf. Attridge (1989:60): "Christ, the creator of earth and heaven, is the creator of the angelic realm."

3 Although scholars refer to this as a metaphor, it is technically more correct to see this comparison as a simile because of the comparative particle $W f$.

4 Others are: Pss 6, 32, 38, 51, 130 and 143 (Kraus 1978b:869; West 1981:445; Weiser 1982:652).

5 According to Goulder (1998:109), the even-numbered Pss 90 and 102 were probably used as evening Psalms.

6 "His own dominion and years will be unending forever" (Lunt 1985:411). Cf. also McLean 1992:76.

7 Bacon, however, argues that "the abrupt form of this citation suggests, this psalm-passage would rather have been a locus classicus of proto-Christian apologetic". He sees a connection via Barn. $4: 3$, which quotes a passage from a lost book of the Enoch literature and applies it similarly to 
Mark 13:20 (par. Matt 24:22), arguing that the passage is from Ps 102:23 (1902:283).

8 Text taken from Ulrich, Cross \& Fitzmyer 2000:39.

9 Cf. Sanders 1965:20; 1967:30-31. Translation: "[They will perish, but thou dost endure;] they will wear out like a garment. And [thou changest them] like raiment, [and they pass away; but thou art the same,] and thy years have no end. The children [of thy servants shall dwell secure; their posterity shall be established before thee,] [generation to generation]."

10 According to Flint (2000:351), also 4QPsb reads here $\mathrm{w}\left[\right.$ nowvith 11QPs ${ }^{\mathrm{a}}$.

11 Text taken from Kasser \& Testuz (1967:200-201).

12 Wevers reckons that the position of kurie ought to be noted here and considers this use of the vocative, which follows the second person singular pronoun, as one of 17 instances in the LXX to be an original gloss (2001:21-35). Olofsson pointed out that this is one of 30 times where kuri 0 appears in the LXX without counterpart in the MT (1998:241). Note, however, its absence in PBod XXIV.

13 So also Cook (1992:122-123). Guthrie makes the observation that it might have been due to "a developing cosmology that understood the heavens as multifaceted" (2007:940), though Ellingworth pointed out that Hebrews "does not develop a cosmology including several heavens" and substantiates his standpoint on Heb 1:2, a i jwne (2000:127). I am more inclined to accept the standpoint of Guthrie in this case - cf. Steyn (2003:1107-1128).

14 Cook further points to the fact that "The added 'waw' has a corresponding addition in LXX, S' and V" (1992:123-124).

15 Contrary to Rüsen-Weinhold (2001:184) who read the plural here also, which must be a lapse, as the reading is clearly singular in this instance and identical to that of the MT. So also Guthrie 2007:940.

16 Ellingworth 2000:126.

17 Cf. the discussion of Brunert 1996:84-85.

18 Olofsson takes the deviation with the Hebrew here as reflecting a possible different Vorlage from the MT (1998:247-248).

$19 \mathrm{D}^{1} \mathrm{~K}$ L P Y $\quad$ 0243. 0278. 33. $1881 \mathfrak{A t}$ lat sy sa $\mathrm{sa}^{\mathrm{ms}}$ bo; Ath.

20 Archer \& Chirichigno are of the opinion "that el i xei" could have been a scribal auditory error for a | I a xei , but since $\mathrm{a}^{*} \mathrm{D}^{*}$ read a | I a xei (and likewise Vulg. ${ }^{\text {Clem}) ~ t h e ~ o r i g i n a l ~ r e a d i n g ~ i n ~ H e b ~}$ 1:12 is debatable" (1983:81). The weight of these two witnesses is, nonetheless, not comparable to that of $\rho^{46} \mathrm{~A} B$.

21 So observed by Grässer 1990:92.

22 For Ahlborn, however, "besteht kein Zweifel" that this was the reading in the Vorlage of the author of Hebrews (1966:115). This is, however, difficult to prove.

23 Kistemaker (1961:26-27), Attridge (1989:61), Rüsen-Weinhold (2001:186) and Guthrie (2007: $941)$, all suspect that this text might have influenced the variant reading.

24 Trotter (1997:98) assumes that the words were added by the author of Hebrews, "apparently "to emphasize that the metaphor of the garment is sustained".

25 Karrer (2002:143) is of the opinion that this phrase might go back to the author's Vorlage "da sie sich in den Rhythmus der Parallelismen im Psalm einfügt". So also U. Rüsen-Weinhold 2001:186-187. 
26 So correctly Kistemaker (1961:26): “Apart from a few minor deviations caused by reasons of emphasis and style...". Also Schröger (1968:66): "ganz geringe Änderungen”, and Wilson (1987:42): "following LXX with some minor changes".

27 Ahlborn wrote: "Der kurio von dem in Ps. 101(102),26ff. gesprochen wird, ist nach dem Verständnis des Hebräerbriefes Christus" (1966:115).

28 Grässer (1990:87-88) formulates it aptly: "Die Zitationsfähigkeit hängt also nicht vom vorgegebenen 'messianischen Character' der Schriftstelle ab, sondern allein von ihrer argumentativen Kraft für den theologischen Gedanken von der Schöpfungsmittlerschaft des Sohnes." Cf. also Van Oyen (1962:19): "De tegenstelling verganklijkheid-onverganklijkheid wordt hier achtergrond en schouwtoneel, door middel waarvan zich het werk der verzoening voltrekt."

29 Grässer (1990:81) talks about "unterschiedlichen Wesen".

30 Ellingworth (2000:120) draws attention to the fact that "Hebrews does not distinguish between angels and other created supernatural forces, nor between different classes of angels".

31 According to Goulder (1998:285, 294), Book IV of the Psalms closed with Pss 103-104 and it "reached a crescendo of praise in Psalms 103 and 104".

32 Also known as Ikhnaton or Amenhotep IV.

33 4Q Works of God reads: "9. [...wi]nds and lightning [...the ser]vants of the holy of ho[lies] going out before him...” (Text taken from García Martínez \& Tigchelaar 1997:788-789).

34 1QH 1:10b-12 reads: "10b. ...powerful spirits, according to their laws, before 11. they became $\mathrm{h}[\mathrm{oly}]$ angels $[\ldots]$ eternal spirits in their realms: luminaries according to their mysteries, 12 . stars according to [their] circuits, [all the stormy winds] according to their roles, lightning and thunder according to their duties..." (Text taken from García Martínez \& Tigchelaar 1997:158-159).

35 Compare, for example, CD-A II (=4Q266 2 II): “5b. ... strength and power and a great anger with flames of fire 6. by the <hand $>$ of all the angels of destruction...." Also 4QJub ${ }^{\text {a }}$ (= Jub 2:14; 4Q216): "5: [the waters and all the spirits who serve before him: the angels of] the presence, the angels of ho[liness,] 6: the an [gels of the spirits of fire, the angels of the spirits of the current] $s$ [and] the angels of the spirits of the [clouds]" (Texts taken from García Martínez \& Tigchelaar 1997:552-553; 460-461).

36 Ps 75:13; Ode 8:65, 86 (Dan 3:65, 86); Sir 39:28.

37 Philo makes reference to oil de; I eitourgoi; qeou, thn oujamion floga ajakaiein kai; zwpur ein epeigomenoi (Somn. 2, 186), as well as to the aggel oi l eit ourgoiv(Virt. 74) and to the l eit ourgoi i qeou'(Mos. 2, 149).

38 Ps 102:21; Sir 10:2; Isa 61:6.

392 Bar 21:7; Jub. 2:2; 1 En. 17:1; 2 En. 29:1; 4 Ezra 8:21-22 (McLean 1992:76).

40 Text taken from Ulrich, Cross \& Fitzmyer 2000:67-68.

41 Text taken from Sanders 1967:160-161.

42 Text taken from Ulrich, Cross \& Fitzmyer 2000:128.

43 Flint (2000:352), however, takes the MT to read here hc[.

44 Barthélemy (1969:106) dates the Papyrus in the $2^{\text {nd }}$ cent. C.E. Pietersma (2000:28), however dates it in the $4^{\text {th }}$ cent. C.E. 
45 Cf. also Kasser \& Testuz (1967:26): “Pareillement, on a p Ñ̃̃̃̃our p neuma passim (mais p neuma 22,36 ) et $p$ ÑÑ̃̃̃our $p$ neuma $\mathrm{i} 41,19$, bien qu'il s'agisse ici le plus souvent de l'esprit de l'homme et non pas du Saint-Esprit."

46 Attridge (1989:58) argues similarly: "the translator of the LXX may have had in mind theophanies in which meteorological phenomena were taken to be transformed angels."

47 See the more extensive discussion on this issue by Rüsen-Weinhold (2001:178-179).

48 The Hebrew J al thean also mean “angel.” Cf. Holladay 1980:196; Jastrow 1950:786. This is also the word that is usually translated with ag g el $0 \sim$ by the LXX translators, including the Psalms (except for Pss 8:5; 77:25; 96:7; and 137:1). Cf. Hatch \& Redpath 1975:7-9.

49 Schröger (1968:57) formulates too strong when he says that "Im masoretischen Text steht in diesem Psalm überhaupt nichts über die Engel."

50 Ellingworth (2000:120) argues, however, that the LXX cannot mean "who makes his angels into winds," but rather "who makes winds his messengers".

51 Cf. Schunack (2002:27) too: "Die Engel sind wandelbare Diener...".

52 An image is available at www.ntgateway.com/resource/image.htm.

53 Published by Gonis, Chapa, Cockle et. al. (1999).

54 Ahlborn (1966:111) correctly says "Mit Ausnahme der beiden letzten Wörter" Ellingworth (2000:121) talks about reproducing the LXX "closely"; and Attridge (1989:57) about a "minor difference".

55 Ahlborn (1966:111) explains this reading as either due to an "Unzialverschreibung von O in E, oder es liegt eine Kontamination vor aus $f$ I eg on und $f$ I oga".

56 Walters (1973:323) states: “...its evidence is not " ${ }^{\mathrm{A}}$ ', but only Bo. Sa. $L^{\mathrm{b}}$ and a corrector of A.”

57 "He who makes his angels spirit, his ministers flames of fire" (Horner 1969:5ff). Cf. Ahlborn (1966:112): “...einer Vorlage, die der vom Verfasser des Hebräerbriefes in seinen Zitaten benutzten Septuaginta-Fassung nahesteht".

58 Kistemaker assumes liturgical connections here: "For reasons of proper balance and rhythm the term puro $\sim \mathrm{floga}$, harmonizing with the preceding $p$ neumat $a$, may have been part of the liturgy of the Church" (1961:24) - and so does Attridge (1989:57) supports "influence of liturgical language".

59 Cf. Mark 3:11; 5:13; Matt 8:16; 12:45; Luke 10:20; 11:26; Acts 8:7; 19:12-13. See also 1 John $4: 1$ regarding the distinction of the $p$ neumat $a$ and Rev 16:13-14 regarding the y eudop r of ht ou p neumat a.

60 Christ is thus "supreme in his divine sovereignty" and the angels "minister while Christ sits enthroned” (Phillips 2006:32).

61 Cf. Van Oyen (1962:17): "De strekking van dit citaat bedoelt de onderworpenheid, creatuurlijkheid en dienstbaarheid der engelen uit te drukken." Also Ellingworth (2000:121): “...the purpose of the quotation is to establish that angels are no more than God's I eit our goiv"

62 Weiss (1991:164) sees v. 14 as the conclusion to the whole "Testimonienreihe". 


\section{BIBLIOGRAPHY}

Ahlborn, E. 1966. Die Septuagintavorlage des Hebraerbriefes (Unpublished PhD dissertation). Göttingen: Georg-August-Universität.

Aling, C. F. 1981. Egypt and bible history. From earliest times to 1000 B.C. Grand Rapids: Baker Book House.

Allen, L. C. 1983. Psalms 101-150 (WBC 21). Dallas: Word Inc.

Archer, G. L. \& G. Chirichigno 1983. Old testament quotations in the new testament. Chicago: Moody Bible Press.

Attridge, H. W. 1989. The epistle to the Hebrews (Hermeneia). Philadelphia: Fortress Press.

Bacon, B. W. 1902. Heb 1,10-12 and the Septuagint Rendering of Ps 102,23. ZNW 3:280-285.

Baly, D. 1974. The geography of the Bible. London: Harper \& Row.

Barthélemy, D. 1969. Le Psautier grec et le Papyrus Bodmer XXIV. RTP 19:106-110.

Breasted, J. H. 1946. A history of Egypt. New York: Charles Scribner's Sons.

Bruce, F. F. 1985. The epistle to the Hebrews (NICNT). Grand Rapids: Eerdmans.

Brunert, G. 1996. Psalm 102 im Kontext des Vierten Psalmenbuches (SBB 30). Stuttgart: Katholisches Bibelwerk.

Burden, J. J. 1991. Psalms 101-119. Kaapstad: NG Kerkuitgewers.

Cody, A. 1960. Heavenly sanctuary and liturgy in the epistle to the Hebrews. St. Meinrad: Grail Publications.

Combrink, H. J. B. 1971. Some Thoughts on the Old Testament Citations in the Epistle to the Hebrews (Ad Hebraeos: Essays on the Epistle to the Hebrews). Neotestamentica 5:22-36.

Cook, J. 1992. On the Relationship between 11QPS a and the Septuagint on the basis of the Computerized Data Base (CAQP). In Septuagint, Scrolls and Cognate Writings. Papers presented to the International Symposium on the Septuagint and Its Relations to the Dead Sea Scrolls and Other Writings (Manchester 1990), edited by G. J. Brooke \& B. Lindars, 107-130. Atlanta: Scholars Press.

De Waard, J. 1965. A comparative study of the old testament text in the dead sea scrolls and in the new testament (STDJ 4, ZWO). Leiden: Brill.

Ellingworth, P. 2000. The epistle to the Hebrews (NIGTC). Grand Rapids: Eerdmans.

Elliott, J. K. 2000. Seven Recently Published New Testament Fragments from Oxyrhynchus. NT 42(3):209-213.

Flint, P. W. 2000. Variant Readings of the Dead Sea Psalms Scrolls against the Masoretic Text and the Septuagint Psalter. In Der Septuaginta-Psalter und seine Tochterübersetzungen. Symposium in Göttingen 1997 (MSU XXIV), edited by A. Aejmelaeus \& U. Quast, 337-365. Göttingen: Vandenhoeck \& Ruprecht,

Fraenkel, D. 2004. Verzeichnis der griechischen Handschriften des Alten Testaments von Alfred Rahlfs,

Bd. I,1. Göttingen: Vandenhoeck \& Ruprecht. García Martínez, F. \& E. J. C. Tigchelaar (editors) 1997 The Dead Sea Scrolls Study Edition. Volume One 1QI-4Q273. Leiden: Brill.

Gonis, N., J. Chapa, W. E. H. Cockle et. al. (editors) 1999. The Oxyrhynchus Papyri, Nos. 4494-4544, Vol. 66. London: Egypt Exploration Society. 
Goulder, M. D. 1998. The Psalms of the return (Book V, Psalms 107-150) (JSOTSupSer 258). Sheffield: Sheffield Academic Press.

Grässer, E. 1990. An die Hebräer. 1. Teilband. Hebr 1-6 (EKK XVII/1). Zürich: Benziger Verlag.

Guthrie, G. H. 2007. Hebrews. In Commentary on the new testament use of the old testament, edited by G. K. Beale \& D. A. Carson, 919-995. Grand Rapids: Baker Academic.

Gzella, H. 2002. Lebenszeit und Ewigkeit. Studien zur Eschatologie und Anthropologie des Septuaginta-Psalters (BBB 134). Berlin: Philo.

Hatch, E. \& H. A. Redpath 1975. A concordance to the Septuagint, Vol I: A-I. Graz: Akademische Druck- u. Verlagsanstalt.

Henze, M. 2005. Psalm 91 in Premodern Interpretation and at Qumran. In Biblical interpretation at Qumran, edited by M. Henze, 168-193. Grand Rapids: Eerdmans.

Holladay, W. L. 1980. A concise Hebrew and Aramaic lexicon of the old testament. Grand Rapids: Eerdmans.

Horner, G. 1969. The coptic version of the New Testament in the southern dialect (Otherwise called Sahidic and Thebaic). Vol V: The epistles of S. Paul. Osnabrück: Otto Zeller.

Hossfeld, F.-L. 2001. Akzentsetzungen der Septuaginta im vierten Psalmenbuch: Ps 90-106 (Ps 89105 bzw.106 LXX). In Der Septuaginta-Psalter. Sprachliche und Theologische Aspekte (HBS 32), edited by E. Zenger, 163-169. Freiburg: Herder.

Humbert, P. 1935. La relation de Genèse 1 et du Psaume 104 avec liturgie du Nouvel-An Israëlite. RHPR 15:1-27.

Jastrow, M. 1950. A Dictionary of the Targumim, the Talmud Babli and Yerushalmi, and the Midrashic Literature, Vol II: 1-t. New York: Pardes Publishing House.

Karrer, M. 2002. Der Brief an die Hebräer. Kapitel 1,1-5,10 (Ökumenischer Taschenbuch-Kommentar zum Neuen Testament 20/1). Gütersloh: Gütersloher Verlagshaus.

Kasser, R. \& M. Testuz (editors) 1967. Papyrus Bodmer XXIV. Psaumes XVII - CXVIII. ColognyGenève: Bibliotheca Bodmeriana.

Katz, P. 1955. jEn puri; flogov . ZNW 46:133-138.

Kistemaker, S. J. 1961. The Psalm citations in the epistle to the Hebrews. Amsterdam: Wed. G. van Soest N.V.

Kistemaker, S. J. 1984. New testament commentary. Exposition of the epistle to the Hebrews. Grand Rapids: Baker Book House.

Klijn, A. F. J. 1975. De Brief aan de Hebreeën (De Prediking van het Nieuwe Testament). Nijkerk: G. F. Callenbach N. V.

Koester, C. 2001. Hebrews (AB 36). New York: Doubleday.

Kraus, H.-J. 1978a. Psalmen 1-59 (BKAT XV/1). Neukirchen-Vluyn: Neukirchener Verlag.

Kraus, H.-J. 1978b. Psalmen 60-150 (BKAT XV/2). Neukirchen-Vluyn: Neukirchener Verlag.

Kraus, H.-J. 1962. Gottesdienst in Israel. München: Kaiser Verlag.

Lunt, H. G. 1985. Ladder of Jacob. In The old testament pseudepigrapha, Vol. 2, edited by J. H. Charlesworth, 401-411. New York: Doubleday.

McLean, B. H. 1992. Citations and allusions to Jewish scripture in early christian and Jewish writings through 180 C.E. Lewiston: The Edwin Mellen Press. 
Metzger, B. M. 1975. A textual commentary on the Greek new testament. London: United Bible Societies.

Mowinckel, S. 2004. The Psalms in Israel's worship (translated by D. R. Ap-Thomas). Grand Rapids: Eerdmans.

Olofsson, S. 1998. Qumran and LXX. In Qumran between the old and new testaments (JSOTSupSer 290), edited by F. H. Cryer \& T. L. Thompson, 231-248. Sheffield: Sheffield Academic Press.

Phillips, R. D. 2006. Hebrews (Reformed Expository Commentary). Phillipsburg: P\&R Publishing.

Pietersma, A. 1978. Two manuscripts of the Greek Psalter in the Chester Beatty library Dublin (Analecta Biblica 77). Rome: Biblical Institute Press.

Pietersma, A. 2000. The Present State of the Critical Text of the Greek Psalter. In Der SeptuagintaPsalter und seine Tochterübersetzungen. Symposium in Göttingen 1997 (MSU XXIV), edited by A. Aejmelaeus \& U. Quast, 12-32. Göttingen: Vandenhoeck \& Ruprecht,

Rogerson, J. \& Davies, P. 1989. The old testament world. Cambridge: Cambridge University Press.

Rüsen-Weinhold, U. 2001. Der Septuaginta-Psalter in seinen verschiedenen Textformen zur Zeit des Neuen Testaments. In Der Septuaginta-Psalter: sprachliche und theologische Aspekte. (HBS 32), edited by E. Zenger, 1-87. Göttingen: Vandenhoeck \& Ruprecht.

Sanders, J. A. 1965. The Psalms scroll of Qumran cave 11 (11QPs ${ }^{a}$ ) (DJD IV). Oxford: Clarendon Press.

Sanders, J. A. 1967. The dead sea Psalm scroll. New York: Correll University Press.

Schröger, F. 1968. Der Verfasser des Hebräerbriefes als Schriftausleger (Biblische Untersuchungen 4). Regensburg: Verlag Friedrich Pustet.

Schunack, G. 2002. Der Hebräerbrief (Zürcher Bibelkommentare). Zürich: Theologischer Verlag Zürich.

Spieckermann, H. 1998. Psalmen und Psalter. Suchbewegungen des Forschens und Betens. In Perspectives in the Study of the Old Testament and Early Judaism. A Symposium in Honour of Adam S. Van der Woude on the Occasion of his $70^{\text {th }}$ Birthday, edited by F. García Martinéz \& E. Noort, 137-153. Leiden: Brill.

Steyn, G. J. 2003. Addressing an Angelomorphic Christological Myth in Hebrews? Hervormde Teologiese Studies 59(4):1107-1128.

Trotter, A. H. 1997. Interpreting the epistle to the Hebrews. Grand Rapids: Baker Books.

Ulrich, E., F. M. Cross, J. A. Fitzmyer et al. (editors) 2000. Qumran Cave 4.XI: Psalms to Chronicles (DJD XVI). Oxford: Clarendon.

Van Oyen, H. 1962³. De Brief aan de Hebreeёn. Nijkerk: G. F. Callenbach N.V.

Vermes, G. 1977. The Dead Sea Scrolls: Qumran in Perspective. London: Collins.

Vos, C. J. A. 2005. Theopoetry of the Psalms. Pretoria: Protea Book House.

Walters, P. 1973. The text of the Septuagint. Its corruptions and their emendation. Cambridge: Cambridge University Press.

Washburn, D. L. 2002. A catalog of biblical passages in the dead sea scrolls (Text-Critical Studies 2). Atlanta: SBL.

Weiss, H.-F. 1991. Der Brief an die Hebräer (KEK 13). Göttingen: Vandenhoeck \& Ruprecht.

Weiser, A. 1982. The Psalms: A commentary (OTL). London: SCM Press. 
Werner, E. 1959. Sacred bridge. London: D. Dobson.

West, J. K. 1981. Introduction to the old testament. New York: Macmillan Publishing Co.

Westcott, B. F. 1974. The epistle to the Hebrews. Grand Rapids: Eerdmans.

Westermann, C. 1980. The Psalms: Structure, content, and message (translated by Ralph D. Gehrke). Minneapolis: Augsburg Publishing House.

Wevers, J. W. 2001. The Rendering of the Tetragram in the Psalter and Pentateuch: A Comparative Study. In The Old Greek Psalter (JSOT SupSer 332), edited by R. J. V. Hiebert, C. E. Cox \& P. J. Gentry. Sheffield: Sheffield Academic Press.

Wilson, R. McL. 1987. Hebrews (NCB Commentary). Grand Rapids: Eerdmans. 